\title{
Genetic variability and distance between Lactuca serriola L. populations from Sweden and Slovenia assessed by SSR and AFLP markers
}

\author{
Michaela Jemelková ${ }^{1}$, Miloslav Kitner $^{1}$, Eva Kř́stková ${ }^{1}$, Ivana Doležalová2 ${ }^{2}$ Aleš Lebeda ${ }^{1 *}$ \\ ${ }^{1}$ Palacký University in Olomouc, Faculty of Science, Department of Botany, Šlechtitelů 27, 78371 Olomouc, Czech \\ Republic \\ ${ }^{2}$ Department of Genetic Resources for Vegetables, Medicinal, and Special Plants of Crop Research Institute in Olomouc, \\ Šlechtitelů 29, 78371 Olomouc, Czech Republic
}

\begin{abstract}
The study involved 121 samples of the common weed, Lactuca serriola L. (prickly lettuce), representing 53 populations from Sweden and Slovenia. The seed materials, originating from different habitats, were regenerated and taxonomically validated at the Department of Botany, Palacký University in Olomouc, Czech Republic. The morphological characterizations of the collected plant materials classified all 121 samples as $L$. serriola $\mathrm{f}$. serriola; one sample was heterogeneous, and also present was L. serriola f. integrifolia. Differences in the amount and distribution of the genetic variations between the two regions were analyzed using 257 amplified fragment length polymorphism (AFLP) and 7 microsatellite (SSRs) markers. Bayesian clustering and Neighbor-Network were used for visualization of the differences among the samples by country. Under the Bayesian approach, the best partitioning (according to the most frequent signals) was resolved into three groups. While the absence of an admixture or low admixture was detected in the Slovenian samples, and the majority of the Swedish samples, a significant admixture was detected in the profiles of five Swedish samples collected near Malmö, which bore unique morphological features of their rosette leaves. The Neighbor-Network analysis divided the samples into 6 groups, each consisting of samples coming from a particular country. Reflection of morphology and eco-geographical conditions in genetic variation are also discussed.
\end{abstract}

Key words: biogeography, Dinaric Alps and the Pannonian Plain, DNA polymorphism, ecology, habitats, morphological variation, prickly lettuce, Scandinavia

\section{Introduction}

Prickly lettuce (Lactuca serriola L., Asteraceae) is the most common species in the genus Lactuca L. (Feráková 1977), and has a circumglobal distribution (Lebeda et al. 2004). It is an annual or winter-annual therophyte (Feráková 1977), and an 'r'strategist (Tilman 1988). Its evolution has trended towards a short life cycle, strong self-fertilization ability, good adaptation for wind dispersal, and quick germination (Frietema de Vries 1992, Lebeda et al. 2001). L. serriola is a drought-tolerant species (Werk and Ehleringer 1986), mainly growing in sunny microhabitats within anthropogenic habitats such as roadsides, railways, dumps, and urban areas (Feráková 1977, Lebeda et al. 2001, 2004); it is considered a good colonist of a wide spectrum of different habitats with different degrees of invasivity. Prickly lettuce is of Euro-Asian origin, also being native in North Africa (Feráková 1977). It has primarily spread in the Mediterranean and the Near East (de Vries 1997, Lebeda et al. 2007a), and is considered an archaeophyte dependent on a culture from the northern part of central Europe (Meusel and Jäger 1992). The species belongs to a group of Mediterranean ruderal plants that have enlarged their distribution area during the last few centuries (Landolt 2001).

The northern boundary of the European distribution area runs near latitude $65^{\circ} \mathrm{N}$ through Finland, and $55^{\circ} \mathrm{N}$ through Great Britain (Feráková 1977). The expanding distribution of this species is accomplished by the transport of reproductive propagules, achenes. The ripened achenes with attached pappus are primarily dispersed by the wind, prob- 
ably also by water (Weaver and Downs 2003). The spread of this species is also closely related with human activities, which primarily produce an increase in their transport (Lebeda et al. 2001). Prickly lettuce has drastically increased its geographical range, invading many European, (North-) American, and Australian regions during the last 50-60 years (de Vries 1996, Lebeda et al. 2001, 2004); recently $L$. serriola has spread as an invasive weed throughout Europe (Lebeda et al. 2004, 2007b, D’Andrea et al. 2009), including Scandinavia (Rydberg 2013). Its synanthropic distribution has also been recorded from Australia, including Tasmania and New Zealand (Burbinge and Gray 1970, Webb et al. 1988), as well as Taiwan (Wang and Chen 2010), North America, southern Africa, and Argentina (Strausbaugh and Core 1978, Zohary 1991, Zuloaga and Morrone 1999). The study by Alexander (2010) supported a genetic basis for the differences in the elevation limits of $L$. serriola populations between two parts of its native and introduced ranges.

Two primary morphological forms are recognized within L. serriola L. based on cauline leaf-shape variability; the pinnatifid-leaved form L. serriola L. f. serriola, and the unlobed-leaved form L. serriola L. f. integrifolia (S.F. Gray) S.D. Prince et R. N. Carter. The serriola form is recorded as the most frequent species, occurring at a very high density in Europe; the form integrifolia is not so common, and has been recorded in e.g., Switzerland, Italy, France, western Germany, the Netherlands, and is prevalent in the UK (Lebeda et al. 2001, 2004, 2007a, b).

Lactuca serriola is the best known wild species of the genus Lactuca, the geographic distribution, morphologi$\mathrm{cal}$, and phenological variations of which have been intensively studied (Lebeda et al. 2004, 2007a, Alexander 2010). L. serriola is also an important genetic resource for new resistance to diseases and pests (Lebeda et al. 2014), abiotic factors, as well as for genes responsible for physiological and quality characters (Lebeda et al. 2007a). Prickly lettuce has been used in commercial lettuce breeding for more than 80 years (Lebeda et al. 2007a), especially as a source of race-specific resistance genes against lettuce downy mildew (Bremia lactucae Regel) (Parra et al. 2016). It has also been used over the last decade in various molecular studies to characterize genetic variation and diversity in both germplasm collections and natural populations (e.g. Koopman et al. 2001, Kitner et al. 2008, 2015).

The most commonly used methods for the analysis of DNA polymorphism include amplified fragment length polymorphism (AFLP; Vos et al. 1995), and microsatellites (simple sequence repeats, SSRs); Simko (2009) contributed significantly to the development of these for the genus Lactuca, and in particular for L. serriola Riar et al. (2011). These markers have been successfully applied in Lactuca research, addressing e.g., the distribution of the genetic variation of prickly lettuce across Europe (Lebeda et al. 2009a), distribution of genetic variation in natural populations of L. serriola, L. saligna, and L. aculeata in Israel (Kitner et al. 2015), or analyses of gene flow from crops to their wild relatives (Uwimana et al. 2012).
Southern / central Sweden is the northern limit of $L$. serriola distribution in Europe; Slovenia represents an area between the Central European and Mediterranean / Balkan distributions (Feráková 1977). The two areas differ in their climatic, ecogeographic, and ecologic conditions. In Slovenia, prickly lettuce is distributed throughout the entire territory, from the lowlands to the mountain regions (Martinčič and Sušnik 1984), and it most often grows in association with Stellarietea mediae - annual weed communities species (Šilc and Košir 2006). In Sweden, L. serriola populations are found in southeastern areas, and mostly grow on surfaces and among stones in dry and sunny exposures (Doležalová et al. 2001).

The genetic structure of populations represented by prickly lettuce plants growing at a specific time in a particular site could emerge in at least four different ways: i) achenes can survive in a soil seed bank for 1 to 3 years (Marks and Prince 1982); at the moment of soil disturbance, the seeds can germinate, and these plants bear/represent "old" genotypes for a given population; ii) plants can grow from achenes newly transported to a particular locality by wind, humans, or other transport mechanisms, with such plants bearing "new" genotypes; iii) plants can grow on permanently disturbed soil from generation to generation, and such plants represent a "modified" genotype resulting from continuous evolution under local conditions; iv) "hybrid" plants may appear after natural hybridization between different plant species within the genus Lactuca.

The main purpose of this research was to describe the differences in genetic variability and population genetic structures between populations of prickly lettuce ( $L a c t u-$ ca serriola) coming from two different and distant biogeographic areas of the species' distribution in Europe.

\section{Materials and methods}

\section{Plant materials}

A set of 121 samples of L. serriola L. plants, representing 53 populations, was collected by the authors in Sweden (47 samples) and Slovenia (74 samples) during 2000 (Doležalová et al. 2001). The collected seed samples were regenerated in a greenhouse at the Department of Botany (Palacký University in Olomouc, Czech Republic). During regeneration, the plants were described morphologically according to Doležalová et al. (2002), and the taxonomic status of each sample was verified (Feráková 1977, Doležalová et al. 2002). From each plant two mature leaves were used for DNA extraction (i.e., 121 samples). Data from the individual samples are provided in On-line Suppl. Tab. 1., with the geographic positions of the collection sites given in Fig. 1.

\section{DNA extraction, SSR, and AFLP analyses}

Total genomic DNA was extracted from $100 \mathrm{mg}$ of fresh leaf tissue using the CTAB method (Kump and Javornik 1996), with minor modifications. After DNA extraction, the 
Tab. 1. Microsatellite (SSR) loci used to assess genetic variability in Lactuca sativa $\mathrm{L}$. and L. serriola $\mathrm{L}$.; $\mathrm{N}_{\mathrm{A}}$ - number of alleles; PIC allelic polymorphic information content.

\begin{tabular}{lcccc}
\hline Marker & Reference & $\mathrm{N}_{\mathrm{A}}$ & $\begin{array}{c}\text { Allele size } \\
(\mathrm{bp})\end{array}$ & PIC (\%) \\
\hline SML-002 & Simko (2009) & 6 & $168-207$ & 0.594 \\
SML-019 & Simko (2009) & 2 & $163-164$ & 0.599 \\
SML-045 & Simko (2009) & 4 & $229-238$ & 0.838 \\
SML-055 & Simko (2009) & 5 & $221-240$ & 1.072 \\
WSULs-18 & Riar et al. (2011) & 4 & $208-235$ & 0.494 \\
WSULs-75 & Riar et al. (2011) & 4 & $161-206$ & 0.684 \\
WSULs-163 & Riar et al. (2011) & 7 & $183-197$ & 1.052 \\
\hline
\end{tabular}

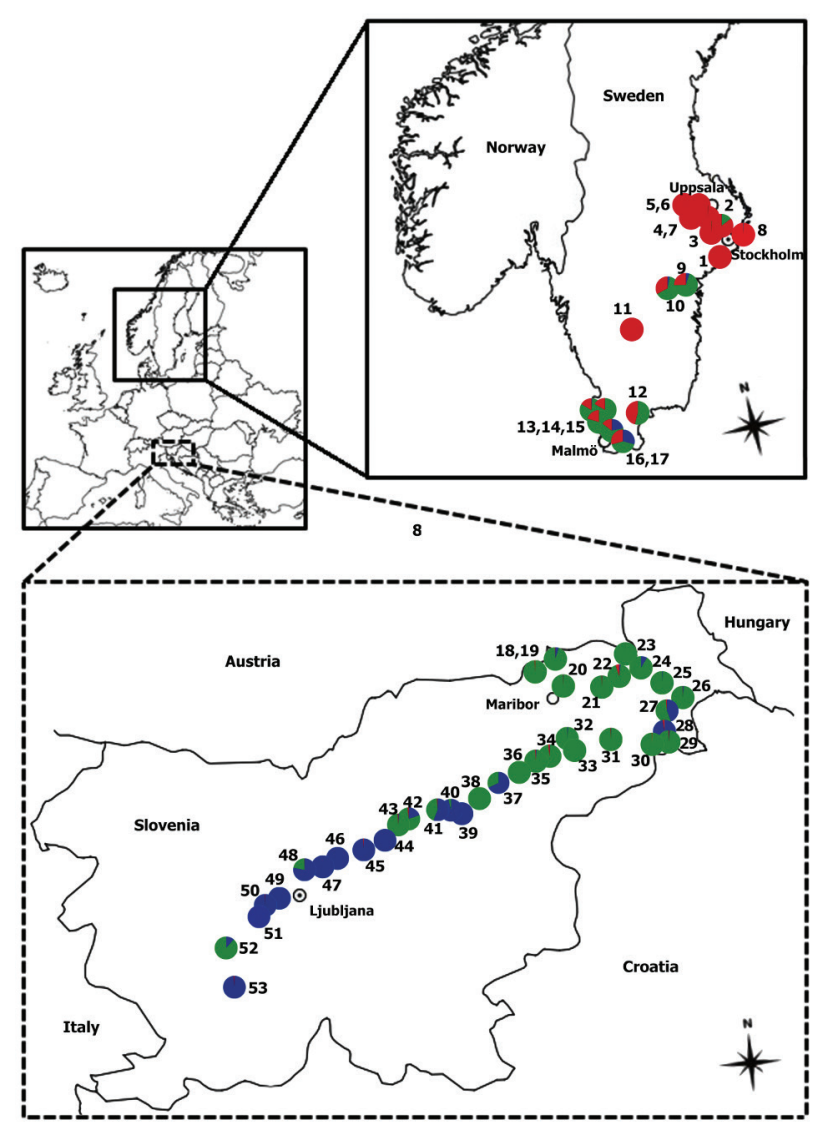

Fig. 1. Collecting sites of the 121 samples Lactuca serriola in Sweden and Slovenia. Colors of spots correspond to the results of Bayesian clustering presented in Fig. 2.

quality of the DNA was inspected by $1.5 \%$ agarose gel electrophoresis, and the concentration measured on a NanoDrop ND-1000 Spectrophotometer (NanoDrop Technologies, Delaware, USA).

For microsatellite genotyping, seven SSR loci were used: SML-002, SML-019, SML-045, SML-055 (Simko 2009), as well as WSULs-18, WSULs-75, and WSULs-163 (Riar et al. 2011). The primer pairs were selected according to their high diversity indices in previously published papers (Simko 2009, Riar et al. 2011); however, randomly without any previous knowledge of their chromosome positions. Amplification of the SSRs was performed according to Jemelková et al. (2015). The length of the SSR alleles was scored based on their migration relative to the molecular weight size markers 30-330bp AFLP ${ }^{\circ}$ DNA ladder (Invitrogen, Carlsbad, California, USA). The AFLP analyses were carried out according to the protocol of Vos et al. (1995), with modifications, and the AFLP fragment detection according to Kitner et al. $(2008,2012)$. Five selective primer combinations, with two to three selective nucleotides, were chosen to generate the AFLP profiles (Tab. 2).

The PCR products were separating on a $6 \%, 0.4 \mathrm{~mm}$ thick denaturating polyacrylamide gel using a T-REX sequencing gel electrophoresis apparatus (Thermo Scientific Owl Separation Systems, Rochester, NY, USA).

Tab. 2. Amplified fragment length polymorphism (AFLP) primer sets for amplification reactions with the total number of scored and polymorphic fragments in the Lactuca serriola samples; $\mathrm{N}_{\mathrm{F}}-$ total number of fragments; $\mathrm{N}_{\mathrm{POL}}$ - number of polymorphic fragments; $\mathrm{P}(\%)$ - percentage of polymorphic fragments.

\begin{tabular}{lccc}
\hline Primer combination & $\mathrm{N}_{\mathrm{F}}$ & $\mathrm{N}_{\mathrm{POL}}$ & $\mathrm{P}(\%)$ \\
\hline E - AGC, M - CTG & 45 & 37 & 82.2 \\
E - AGC, M - CAAC & 49 & 36 & 73.5 \\
E - AGC, M - CAAT & 72 & 54 & 75.0 \\
E - ACC, M - CAAC & 43 & 35 & 81.4 \\
E - ACC, M - CAAT & 48 & 30 & 62.5 \\
Total & 257 & 192 & \\
Mean & 51.4 & 38.4 & 74.9 \\
\hline
\end{tabular}

\section{Data scoring}

Microsatellite profiles were scored based on the length of the PCR product. The allele frequencies, percentage of polymorphic loci (P\%), number of private alleles (PA), observed and expected heterozygosity $\left(\mathrm{H}_{\mathrm{O}}\right.$ and $\left.\mathrm{H}_{\mathrm{E}}\right)$ were all performed using GenAlEx 6 software (Peakall and Smouse 2012). The mean number of alleles per locus (A) was calculated manually. The relative discriminatory value of each microsatellite locus was estimated by the polymorphic information content (PIC), which measures the information content as a function of a marker system's ability to distinguish between genotypes (Powell et al. 1996). The number of different genotypes $\left(\mathrm{N}_{\mathrm{G}}\right)$, number of samples with a heterozygous constitution $\left(\mathrm{N}_{\mathrm{HET}}\right)$, and maximal number of heterozygous loci $\left(\mathrm{N}_{\text {HETmax }}\right)$ were calculated manually.

AFLP profiles were checked visually, and only clear and unambiguous bands were scored for their presence (1) or absence (0) across all samples. For AFLP data, the number of private bands (PA), the proportion of polymorphic loci $(\mathrm{P} \%)$ and gene diversity $\left(\mathrm{H}_{\mathrm{E}}\right)$ were calculated using GenAlEx 6 software (Peakall and Smouse 2012).

To evaluate the population genetic structure, a Bayesian clustering approach was used as implemented in Structure 
2.3.4 (Falush et al. 2007). Structure attempts to assign individuals to clusters/groups/populations on the basis of their genotypes, while simultaneously estimating population allele frequencies. This allows one to compute the likelihood of a given genotype having originated in a predefined number $(\mathrm{K})$ of clusters. In the simplest, 'no-admixture' model, it assumes that each individual belongs to a single cluster. In the more general 'admixture model' it estimates admixture proportions for each individual, allowing one to identify admixed individuals represented by a proportional mixture of two or more signals characteristic for the various clusters. In our analyses, SSR co-dominant data were transferred into binary data based on the presence/absence of a particular allele, and merged with the AFLP binary data; the samples were then ordered according to the increasing latitude of the sampling site within a particular country. An admixture model was used, with correlated allele frequencies. $\mathrm{K}$ was set at $1-10$, and the highest $K$ value was identified as the run with the highest likelihood value, as recommended by Pritchard et al. (2000). In addition, K values were averaged across 10 replicate runs for each K (100 000 burn-in iteration followed by $1000000 \mathrm{MCMC}$ iterations). For the graphical interpretation of clustering for the appropriate K, Structure Harvester (Earl and von Holdt 2012), Clumpp (Jacobsson and Rosenberg 2007), and Distruct (Rosenberg 2004) software packages were used. The optimal K value was selected according to Evanno et al. (2005), who suggested the use of the $\Delta \mathrm{K}$ value for identifying the correct number of clusters.

To visualize the genetic relationships within and among the analyzed samples, a Neighbor-Network based on Dice's similarity coefficient (D) was constructed in SplitsTree 4 (Huson and Bryant 2006). The Nexus input file for SplitsTree 4 was exported from GenAlEx. Also, for this purpose, the SSR data were transformed into a binary matrix and merged with the AFLP binary data. The reliability and robustness of the network were tested by bootstrap analysis with 1.000 bootstrap replicates.

\section{Results}

\section{Taxonomic verification of $L$. serriola}

For all 121 plants, the taxonomic status of Lactuca serriola f. serriola according to Feráková (1977) was confirmed. Moreover, in one sample (no. 205_00, Bostahusen, Sweden) the plants were morphologically heterogeneous; with divided stem leaves belonging to $L$. serriola $\mathrm{f}$. serriola, plants with entire stem leaves that ranged toward L. serriola $\mathrm{f}$. integrifolia. In our analyses, this sample was split into two subsamples 205_00A (f. serriola) and 205_00B (f. integrifolia) and treated (analyzed) separately.

\section{Genetic polymorphism}

The seven polymorphic SSR loci produced a total of 32 alleles across the 121 individual $L$. serriola plants. The number of alleles per locus ranged from 2 to 7, with an aver- age of 4.57 alleles per locus (Tab. 1). The allele sizes varied from 161 to $240 \mathrm{bp}$. The mean PIC per SSR polymorphic allele was 0.762 , within a range of 0.494 to 1.072 . Null alleles only appeared in two accessions from Slovenia (13_00 and 22_00) at the locus SML-055.

Private alleles (PA) were present within both sampled regions (Tab. 3). The L. serriola samples from Sweden possessed 5 unique alleles: 193 bp, 204 bp, and 207 bp for locus SML-002, 221 bp for locus SML-055 (i.e., 221

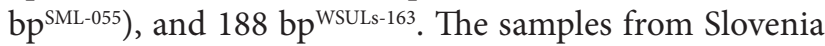
possessed eight unique alleles: $172 \mathrm{bp}, 198 \mathrm{bp}$ for locus SML-002, $238 b^{\text {SML-045 }}, 228 \mathrm{bp}^{\text {SML-055; }} 217 \mathrm{bp}$ and $235 \mathrm{bp}$ for locus WSULs-18, and lastly $183 \mathrm{bp}$ and $195 \mathrm{bp}$ for locus WSULs-163.

The observed and expected heterozygosity $\left(\mathrm{H}_{\mathrm{O}}\right.$ and $\mathrm{H}_{\mathrm{E}}$ ) ranged from 0.036 to 0.054 (mean 0.045 ), and from 0.341 to 0.432 (mean 0.387 ), respectively. The proportion of polymorphic loci (P\%) was higher in the Slovenian (84.4\%) than in the Swedish samples (75\%). Based on SSR data, in all, 51 different genotypes $\left(\mathrm{N}_{\mathrm{G}}\right)$ were recognized (Sweden $=17$; Slovenia $=34)($ On-line Suppl. Tabs. 2,3). Genotype G3 was the most common in the samples from Sweden (36.2\%), while genotype G29 represented $32.4 \%$ of the Slovenian samples (On-line Suppl. Tabs. 2,3). We recorded 17 Slovenian samples that had at least one heterozygous locus $\left(\mathrm{N}_{\mathrm{HET}}=17\right)$, in contrast to eight samples from Sweden (On-line Suppl. Tabs. 2,3). Three samples from Slovenia and one sample from Sweden bore the maximum number of heterozygous loci $\left(\mathrm{N}_{\text {HETmax }}=3\right)$ observed from among all analyzed samples.

In total, five primer combinations, with two to three selective bases, were applied for AFLP genotyping (Tab. 2), resulting in 257 unambiguously scored fragments. Detailed overall statistics calculated for each primer combination used are presented in Table 2. The number of private bands (PA) ranged from 19 (Slovenian samples) to 20 (Swedish samples). The expected heterozygosity $\left(\mathrm{H}_{\mathrm{E}}\right)$ ranged from 0.130 to 0.149 (mean $\mathrm{H}_{\mathrm{E}}=0.140$ ) (Tab. 3), and the proportion of polymorphic loci (P\%) in the L. serriola samples ranged from $44.8 \%$ (Swedish population) to $52.9 \%$ (Slovenian population). The genetic variability indices for all populations are summarized in Table 3.

\section{Cluster analysis of molecular data}

Based on seven microsatellite and 257 AFLP markers, Bayesian clustering and construction of a Neighbor-Network were used for visualization of the putative relationships among the analyzed individuals. Under the Bayesian approach implemented in Structure, the best partition into three clusters $(K=3$, Fig. 2$)$ was resolved $(\Delta K=214.73$; St. dev. $\operatorname{LnP}(K)=6.07)$; they are represented by the green (Gcluster), red (R-cluster), and blue (B-cluster) color signals in Figure 2. In general, a relatively low admixture was detected in the Slovenian samples, which were clearly identified as genotypes from the G- or B-cluster. While the B-cluster can be considered as characteristic for L. serriola genotypes 


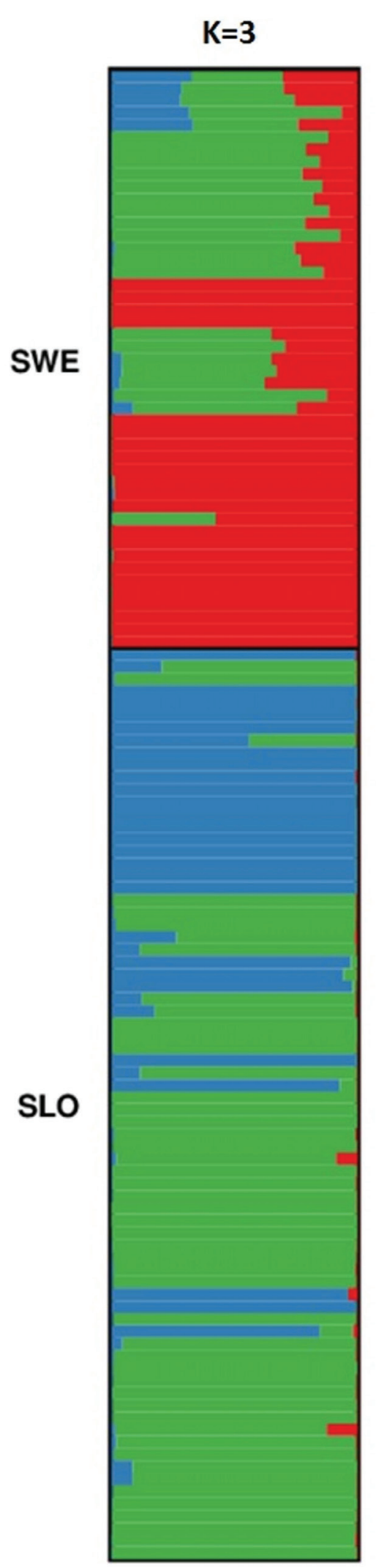

Fig. 2. Results of Bayesian clustering based on the microsatellite (SSR) and amplified fragment length polymorphism (AFLP) data of 121 Lactuca serriola samples from Sweden (SWE) and Slovenia (SLO), ordered according to the increasing latitude of the sampling site within a specific country. Each individual is represented by a horizontal line partitioned into segments of different color, the lengths of which indicate the posterior probability of membership in each group as identified by Structure. from the southern part of Central Europe and the northern Balkans (representing ca. 1/3 of the Slovenian samples), the G-cluster represents the genotype largely dispersed across Europe, contributing significantly to the genotypic composition of the Swedish populations. The signal characteristic for genotypes from the R-cluster was nearly absent in the Slovenian samples, but was recorded in each sample from Sweden; and $48.9 \%$ of the Swedish samples fell into the Rcluster with no admixture signal (Fig. 2). For 19 samples, the signal from the R-cluster contributes up to $30 \%$ of a particular genotype, and is accompanied with an admixture of the $G$ signal, which prevails in the Slovenian samples (Fig. 2). Further, we observed a nearly equal admixture of signals from all three clusters in five samples collected in southern Sweden near Malmö.

The Neighbor-Network analysis divided the analyzed samples into 6 groups (A-F; Fig. 3), each consisting of samples coming from a separate country. The results fit the results of the Bayesian clustering in terms of assigning individuals from a separate country to the revealed clusters (R-, G-, B-). The samples from Sweden were placed into the A, $\mathrm{C}$, and D groups. While individuals placed in Group C represent the genotype from the R-cluster, Group D is formed by samples with the G-cluster prevailing. Finally, Group A is formed by five samples 215_00, 217_00, 218_00, 219_00, and 220_00, having a strong admixture signal from all three Structure clusters. These samples represent populations no. 16 and 17 from collecting sites close to Malmö (On-line Suppl. Tab. 1). The samples from Slovenia were split into three groups: a majority of the samples fell in groups B and E, both representing the G-cluster in Fig. 2. Samples originating from Slovenian localities below $46^{\circ} 14^{\prime} 34^{\prime \prime}$ lat. fell into a separate Group F, which represents genotypes from a unique B-cluster (Fig. 2). It is interesting, that all three

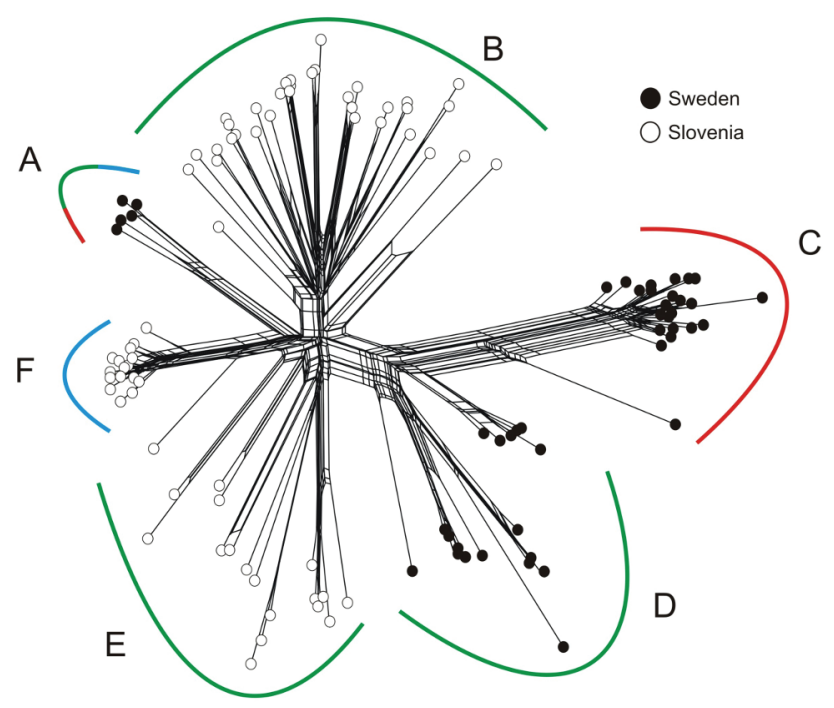

Fig. 3. Neighbor-Network cluster analysis of 121 samples Lactuca serriola from Sweden and Slovenia, based on SSR and AFLP analysis. Resulting groups are highlighted by coloring that corresponds to the results of Bayesian clustering presented in Fig. 2. 
Tab. 3. Summary data based on 7 SSR and 257 amplified fragment length polymorphism (AFLP) loci of 121 Lactuca serriola samples from Sweden and Slovenia in recent study: $\mathrm{N}$ - sample size; $\mathrm{PA}_{\mathrm{SSR}}$ - private microsatellite alleles; $\mathrm{PA}_{\mathrm{AFLP}}$ - private AFLP bands; A - mean number of alleles per locus; $\mathrm{P}(\%)$ - percentage of polymorphic loci; observed $\mathrm{H}_{\mathrm{o}}$ and expected $\mathrm{H}_{\mathrm{e}}$ heterozygosity; $\mathrm{SE}$ - standard error.

\begin{tabular}{|c|c|c|c|c|c|c|c|c|c|}
\hline \multirow{2}{*}{ Country } & \multirow{2}{*}{$\mathrm{N}$} & \multicolumn{5}{|c|}{ Microsatellite (SSR) data } & \multicolumn{3}{|c|}{ AFLP data } \\
\hline & & $\mathrm{PA}_{\mathrm{SSR}}$ & A & $\mathrm{P}(\%)$ & $\mathrm{H}_{\mathrm{O}}$ & $\mathrm{H}_{\mathrm{E}} \pm \mathrm{SE}$ & $\mathrm{PA}_{\mathrm{AFLP}}$ & $\mathrm{P}(\%)$ & $\mathrm{H}_{\mathrm{E}} \pm \mathrm{SE}$ \\
\hline Sweden & 47 & 5 & 3.42 & 75.0 & 0.036 & $0.341 \pm 0.065$ & 20 & 44.8 & $0.130 \pm 0.011$ \\
\hline Slovenia & 74 & 8 & 3.86 & 84.4 & 0.054 & $0.432 \pm 0.049$ & 19 & 52.9 & $0.149 \pm 0.011$ \\
\hline
\end{tabular}

"G-cluster" groups from both countries are in the center of the Neighbor-Network, which resemble their characteristics closely. On the other hand, Group C (SWE, R-cluster) and Group F (SLO, B-cluster) are placed on opposite sides of the network.

\section{Discussion}

Verification of the taxonomic status of the plants showed that Lactuca serriola f. serriola is predominant in both countries. In the entire territory of Slovenia only L. serriola f. serriola was recorded, which is in agreement with previous observations in Central Europe (Lebeda et al. 2001, 2004, 2007b). Within one sample from southern Sweden (Bostahusen, sample 205_00), apart from L. serriola f. serriola plants, there were plants identified as $L$. serriola $\mathrm{f}$. integrifolia. All remaining samples from Sweden were represented only by $L$. serriola $\mathrm{f}$. serriola. It is evident that both populations are very taxonomically homogeneous on the subspecific level. The very rare occurrence of $L$. serriola $\mathrm{f}$. integrifolia in southern Sweden could be caused by the repeated introduction (e.g., through truck or ship transportation) of this form from the Netherlands or UK, where it is prevalent (Lebeda et al. 2007a, b). However, from our previous results (Doležalová et al. 2001) it is evident, that this variety is not spreading into northern Scandinavia, where the northern limit of the European distribution for this species is (Feráková 1977). These conclusions are supported by recent observations in Sweden made by Rydberg (2013). Also, in Norway only L. serriola f. serriola has been recorded (Lebeda 2013, unpubl. results).

The leaf shape (i.e., the division of the leaf blade), can be interpreted as an ecological adaptation of the plant to different factors, including a means of leaf thermoregulation in arid or hot environments, or in reaction to hydraulic constraints (Nicotra et al. 2011). Doležalová et al. (2009) also confirmed the differences in the morphology of rosette and cauline leaves of Swedish and Slovenian L. serriola samples. The cauline leaves of Swedish L. serriola plants were longer and wider; plants from Slovenia had longer and narrower rosette leaves (divided) (Doležalová et al. 2009). The width and length of cauline leaves (divided) correlate with the latitude, which could be explained as adaptations of the plants to drought. Drier areas of lower latitudes are increasingly represented by plants with smaller leaves. Regarding alti- tude, a negative correlation with the length and width of the leaves was found (Doležalová et al. 2009), which could mean they are adapting to ecologically worse conditions at higher elevations. The occurrence of $L$. serriola f. integrifolia in temperate areas without a dry season (but with a warm summer) in the UK, western part of Germany, Benelux, and France (Peel et al. 2007) supports the theory of the ecological adaptation of leaves presented by Nicotra et al. (2011). The areas in Sweden where lettuce samples were collected belong to the cold climate type, without a dry season or warm summer (Peel et al. 2007). Similarly significant differences in morphological parameters of achenes of L. serriola from Slovenia and Sweden were found between populations within countries and between samples within population (Kř́stková et al. 2014).

The higher phenotypic and genetic variability of the Slovenian samples can be explained by the more favorable climatic and ecological conditions in the country (see Peel et al. 2007). L. serriola is distributed throughout the entire country, and movement of diaspores among the surrounding countries is feasible (Lebeda et al. 2004). This is in opposition to Sweden, where the distribution is limited to the southern part (Doležalová et al. 2001), with very limited migration from the surrounding countries. In general, plant species occurring almost in and/or near the center of their diversity, with suitable environmental and ecological conditions, display more genetic/phenotypic variability. Conversely, at the edge of the distribution area, where less favorable conditions exist, the selection prioritizes stable and well-adapted genotypes. Our results on genetic variability are in relationship to the general principles of diversity and allele distribution formulated by Vavilov (1950). Kuang et al. (2008) suggested that eastern Turkey and Armenia, along with the surrounding regions, might be the center of diversity of $L$. serriola (and possibly its center of origin). L. serriola might have spread from its center of origin first to the Mediterranean basin and then to Central and Western Europe after the glaciers retreated in the Upper-Pleistocene / Holocene period (Kuang et al. 2008). Recent climatic changes and anthropogenic disturbances contributed substantially to the rapid spread of L. serriola into new areas (D'Andrea et al. 2009, Rydberg 2013), as well as increasing the genetic diversity of their populations in the central parts of their natural distribution areas (Lebeda et al. 2009a, van de Wiel et al. 2010, Kitner et al. 2015). This phenomenon 
was also clearly demonstrated in the genetic diversity of the Central European population of $L$. serriola (van de Wiel et al. 2010), as well as the resistance of the same population to Bremia lactucae. While the Czech Republic has the greatest diversity of resistance phenotypes, the lowest was recorded in the UK (Lebeda et al. 2008, Petrželová and Lebeda 2011).

The results of our study on genetic variability are in good agreement with the different climatic conditions in Sweden and Slovenia. From the viewpoint of genetic variation, the results have proven the existence of $L$. serriola genotypes characteristic for each country. These clearly differ from one another, as is evident from Bayesian clustering and Neighbor-Network analysis, where the R-cluster characteristic for the Swedish samples (Group C), and the B-cluster (Group F) unique for Slovenian samples were distinguished (Figs. 2, 3). A number of samples from both countries were characterized by genotypes characteristic for the G-cluster, which might represent a common genotype resulting from the rapid spread of $L$. serriola in Central Europe (Lebeda et al. 2001, 2007b, D'Andrea et al. 2009). We have not recorded a prevailing microsatellite genotype for the samples representing this G-cluster, and no linkage to the latitude or altitude of the sampled sites. The same phenomenon was described by Lebeda et al. (2009a), demonstrating that some L. serriola populations (e.g., Scandinavian, British, some Mediterranean) are quite isolated genetically from the heterogeneous Central and West European populations. Genetic analysis (PCR-RFLP and SSR markers) on 101 populations of L. serriola from seventeen countries of Western and Central Europe made by D'Andrea et al. (2017) revealed a strong genetic differentiation between populations, and high inbreeding coefficients within populations. A clear geographical pattern of isolation by increasing distance was found; however, only a weak pattern of correlation between genetic diversity and geographical distance was found on the continental scale. The greatest amount of genetic diversity was characterized in Central Europe, while populations from the western Mediterranean (Spain and Portugal), southern Italy, Great Britain, the Alps, and southern Scandinavia generally possessed lower gene diversities (D'Andrea et al. 2017). Discrepancies were present in Scandinavia with some polymorphic populations, and a monomorphic one. Further, in a recent study, higher genetic variability in the Slovenian samples was observed in terms of the recorded genetic variability indices (Tab. 3) and the higher number of SSR genotypes $\left({ }^{\mathrm{SWE}} \mathrm{N}_{\mathrm{G}}=17 /^{\mathrm{sLO}} \mathrm{N}_{\mathrm{G}}=34\right.$ ) (On-line Suppl. Tabs. 2,3). The level of genetic variation within and between populations can also result from intraspecific crossing. Although autogamy is the predominant breeding system within the genus Lactuca L., especially in the marginal parts of the distribution area (Feráková 1977); in the center of the distribution, a higher occurrence of allogamy was estimated (Stebbins 1957). Lindquist (1960) proved experimentally that all species belonging to the "serriola" group were self-fertile. L. serriola is primarily a self-pollinated species; however, not only in- termediate plants between the two L. serriola forms, but also interspecific hybrids of $L$. serriola can be detected in natural populations (Zohary 1990, Kř́stková et al. 2012). The main differences between the samples from Sweden and Slovenia can be characterized by the presence of genotypes characteristic for the R- or B-cluster, determined by Bayesian clustering (Fig. 2), each unique (with a few exceptions) to a given country. The signal from the R-cluster was present in all Swedish samples and prevails in $48.9 \%$ of them. These samples formed Group C on the NeighborNetwork (Fig. 3), 65.2\% of them represent the SSR genotype G3, with a completely homozygous character at all loci, and originating from localities at a higher latitude (On-line Suppl. Tab. 2).

A rather interesting characteristic of five L. serriola samples was found in a group of plants collected near Malmö. These samples forming Group A on the Neighbor-Network, are represented by a significant admixture signal on the Bayesian diagram, and also bore unique morphologi$\mathrm{cal}$ features of their rosette leaves. The apical parts of the rosette leaves in samples 215_00, 217_00, 218_00, 219_00, and 220_00 were not divided, forming a long apex; the remaining two-thirds of the leaves were slightly divided (pinnately lobed). Surprisingly, specific DNA patterns fit better to specific phenotypes of the rosette leaves than to phenotypes of the cauline leaves. This is in contrast to the generally accepted view that morphological traits of the cauline leaves have a more significant taxonomic value than do the rosette leaves. The city of Malmö is an international harbor in the region, and it is possible to explain the exceptional phenotypic characteristics of these samples by the human-moderated introduction of non-indigenous genotypes into the southern parts of northern Europe, with subsequent natural hybridization with indigenous L. serriola genotypes. The Bcluster in Slovenian samples showed, with a few exceptions, a continuity with samples from a lower latitude; $96 \%$ of these samples are represented by the completely homozygous microsatellite genotype G29 (On-line Suppl. Tab. 3).

This study provides interesting insights into the genetic variability of $L$. serriola populations originating from completely different eco-geographical areas. Specifically those from Slovenia, near the Mediterranean, a world diversity hotspot (Myers et al. 2000), the center of the greatest diversity of the genus Lactuca (Lebeda et al. 2009b); additionally, those from Sweden, a region at the northern border of L. serriola European distribution (Feráková 1977, Lebeda et al. 2004). This study showed that $L$. serriola populations originating from various eco-geographical conditions differ significantly in their genetic background, which is also reflected in the geographic patterns of their phenotypic features. To obtain more comprehensive information on the genetic structure and variations of this species, it would be interesting to analyze: i) more populations with more individuals from Sweden, and for a comparative study ii) additional samples originating from areas with greater contrasting ecological conditions. 


\section{Acknowledgments}

This study was supported projects MSM 6198959215 (Ministry of Education, Youth and Sports) and QH 71254
(Czech Ministry of Agriculture), and by the Internal Grant Agency of Palacký University in Olomouc (IGA Prf_2015_001, IGA_Prf_2016-001, IGA_PrF_2017_001, IGA_PrF_2018_01).

\section{References}

Alexander, J. M., 2010: Genetic differences in the elevational limits of native and introduced Lactuca serriola populations. Journal of Biogeography 37, 1951-1961.

Burbinge, N. T., Gray, M., 1970: Flora of the Australian capital territory. Australian National University Press, Canberra, Australia.

D’Andrea, L., Broennimann, O., Kozlowski, G., Guisan, A., Morin, X., Keller-Senften, J., Felber, F., 2009: Climate change, anthropogenic disturbance and the northward range expansion of Lactuca serriola (Asteraceae). Journal of Biogeography 36, 1573-1587.

D’Andrea, L., Meirmans, P., van de Wiel, C., Guadagnuolo, R., van Treuren, R., Kozlowski, G., den Nijs, H., Felber, F., 2017: Molecular biogeography of prickly lettuce (Lactuca serriola L.) shows traces of recent range expansion. Journal of Heredity $108,194-206$.

de Vries, I. M., 1996: Characterization and identification of Lactuca sativa cultivars and wild relatives with SDS-electrophoresis (Lactuca sect. Lactuca, Compositae). Genetic Resources and Crop Evolution 43, 193-202.

de Vries, I. M., 1997: Origin and domestication of Lactuca sativa L. Genetic Resources and Crop Evolution 44, 165-174.

Doležalová, I., Křístková, E., Lebeda, A., Vinter, V., 2002: Description of morphological characters of wild Lactuca L. spp. genetic resources (English-Czech version). Horticultural Science $29,56-83$.

Doležalová, I., Lebeda, A., Kř́stková, E., 2001: Prickly lettuce (Lactuca serriola L.) germplasm collecting and distribution study in Slovenia and Sweden. Plant Genetics Resources Newsletter 128, 41-44.

Doležalová, I., Lebeda, A., Špoková, M., Kř́stková, E., 2009: Comparison of phenotypic variability of Lactuca serriola genetic resources from Slovenia and Sweden. In: Meglic, V., Bastar, M.T. (eds.) Book of Abstracts of 19th EUCARPIA Conference, Genetic Resources Section, Ljubljana, Slovenia, May 26-29, 2009. Kmetijski Institut Slovenije, Ljubljana, 51. ISBN 978-961-6505-40-6.

Earl, D. A., von Holdt, B. M., 2012: Structure Harvester: a website and program for visualizing Structure output and implementing the Evanno method. Conservation Genetics Resources 4, 359-361.

Evanno, G., Regnaut, S., Goudet, J., 2005: Detecting the number of clusters of individuals using the software STRUCTURE: a simulation study. Molecular Ecology 14, 2611-2620.

Falush, D., Stephens, M., Pritchard, J. K., 2007: Inference of population structure using multilocus genotype data: dominant markers and null alleles. Molecular Ecology Notes 7, 574578.

Feráková, V., 1977: The genus Lactuca L. in Europe. Univ. Komenského, Bratislava, Czechoslovakia.

Frietema de Vries, F. T., 1992: The systematic relationship of Lactuca sativa and Lactuca serriola, in relation to the distribution of prickly lettuce. Acta Botanica Neerlandica 43, 79 .

Huson, D. H., Bryant, D., 2006: Application of phylogenetic networks in evolutionary studies. Molecular Biology and Evolution 23, 254-267.

Jacobson, M., Rosenberg, N. A., 2007. CLUMPP: a cluster matching and permutation program for dealing with label switching and multimodality in analysis of population structure. Bioinformatics 23, 1801-1806.

Jemelková, M., Kitner, M., Kř́ístková, E., Beharav, A., Lebeda, A., 2015: Biodiversity of Lactuca aculeata germplasm assessed by SSR and AFLP markers, and resistance variation to Bremia lactucae. Biochemical Systematics and Ecology 61, 344-356.

Kitner, M., Lebeda, A., Doležalová, I., Maras, M., Křístková, E., Nevo, E., Pavlíček, T., Meglic, V., Beharav, A., 2008: AFLP analysis of Lactuca saligna germplasm collections from four European and three Middle Eastern countries. Israel Journal of Plant Sciences 56, 185-193.

Kitner, M., Majeský, L., Gillová, L., Vymyslický, T., Nagler., M., 2012: Genetic structure of Artemisia pancicii populations inferred from AFLP and cpDNA data. Preslia 84, 97-120.

Kitner, M., Majeský, L., Křístková, E., Jemelková, M., Lebeda, A., Beharav, A., 2015: Genetic diversity in Israeli natural populations of three predominantly self-pollinating wild Lactuca ( $L$. serriola, L. saligna, L. aculeata) species. Genetics Resources and Crop Evolution 67, 991-1008.

Koopman, W. J. M., Zevenbergen, M. J., Van den Berg, R. G., 2001: Species relationships in Lactuca s.l. (Lactuceae, Asteraceae) inferred from AFLP fingerprints. American Journal of Botany $88,1881-1887$.

Křístková, E., Lebeda, A., Kitner, M., Vafková, B., Matoušková, Z., Doležalová, I., Beharav, A., 2012: Phenotypes of the natural interspecific hybrids in the genus Lactuca. Uroda 60/9, 28-31.

Kř́stková, E., Lebeda, A., Novotná, A., Doležalová, I., Berka, T., 2014: Morphological variation of Lactuca serriola L. achenes as a function of their geographical origin. Acta Botanica Croatica $73,1-19$.

Kuang, H., van Eck, H. J., Sicard, D., Michelmore, R., Nevo, E., 2008: Evolution and genetic population structure of prickly lettuce (Lactuca serriola) and its RGC2 resistance gene cluster. Genetics 178, 1547-1558.

Kump, B., Javornik, B. 1996: Evaluation of genetic variability among common buckwheat (Fagopyrum esculentum Moench) populations by RAPD markers. Plant Science 114, 149-158.

Landolt, E., 2001: Flora der stadt Zürich. Birkhäuser Verlag, Basel, Switzerland.

Lebeda, A., Doležalová, I., Feráková, V., Astley, D. 2004: Geographical distribution of wild Lactuca species (Asteraceae, Lactuceae). The Botanical Review 70, 328-356.

Lebeda, A., Doležalová, I., Křístková, E., Dehmer, K. J., Astley, D., van de Wiel, C. C. M., van Treuren, R., 2007b: Acquisition and ecological characterization of Lactuca serriola L. germplasm collected in the Czech Republic, Germany, the Netherlands and United Kingdom. Genetics Resources and Crop Evolution $54,555-564$

Lebeda, A., Doležalová, I., Křístková, E., Kitner, M., Petrželová, I., Mieslerová, B., Novotná, A., 2009b: Wild Lactuca germplasm for lettuce breeding: current status, gaps and challenges. Euphytica 170, 15-34.

Lebeda, A., Doležalová, I., Kř́stková, E., Mieslerová, B., 2001: Biodiversity and ecogeography of wild Lactuca spp. in some European countries. Genetics Resources and Crop Evolution 48, 153-164.

Lebeda, A., Křístková, E., Kitner, M., Mieslerová, B., Jemelková, M., Pink, D. A. C., 2014: Wild Lactuca species, their genetic 
diversity, resistance to diseases and pests, and exploitation in lettuce breeding. European Journal of Plant Pathology 138, 597-640.

Lebeda, A., Kitner, M., Dziechciarková, M., Doležalová, I., Křístková, E., Lindhout, P., 2009a: An insight into the genetic polymorphism among European populations of Lactuca serriola assessed by AFLP. Biochemical Systematics and Ecology 37, 597-608.

Lebeda, A., Petrželová, I., Maryška, Z., 2008: Structure and variation in the wild-plant pathosystem: Lactuca serriola - Bremia lactucae. European Journal of Plant Pathology 122, 127-146.

Lebeda, A., Ryder, E. J., Grube, R., Doležalová, I., Kř́stková, E., 2007a: Lettuce (Asteraceae; Lactuca spp.), Chapter 9, 377472. In: Singh, R. (ed.): Genetic resources, chromosome engineering, and crop improvement series, Volume 3 - Vegetable Crops. CRC Press, Boca Raton, FL, USA.

Lindqvist, K., 1960: Cytogenetic studies in the serriola group of Lactuca. Hereditas 46, 75-151.

Marks, M. K., Prince, S. D., 1982: Seed physiology and seasonal emergence of wild lettuce Lactuca serriola. Oikos 38, 242-249.

Martinčič, A., Sušnik, F., 1984: Lactuca L. - Ločika. In Mala flora Slovenije. Država založba Slovenije, Ljubljana, 601-602 (in Slovenian).

Meusel, H., Jäger, E. J., 1992: Vergleichende Chorologie der Zentraleuropäischen Flora. Text. Band III. Gustav Fischer Verlag, Jena-Stuttgart-New York.

Myers, N., Mittermeier, R. A., Mittermeier, C. G., da Fonseca, G. A. B., Kent, J., 2000: Biodiversity hotspots for conservation priorities. Nature 403, 853-858.

Nicotra, A. B., Leigh, A., Boyce, C. K., Jones, C. S., Niklas, K. J., Royer, D. L., Tsukaya, H., 2011: The evolution and functional significance of leaf shape in the angiosperms. Functional Plant Biology 38, 535-552.

Parra, L., Maisonneuve, B., Lebeda, A., Schut, J., Christopoulou, M., Jeuken, M., McHale, L., Truco, M. J., Crute, I., Michelmore, R., 2016: Rationalization of genes for resistance to Bremia lactucae in lettuce. Euphytica 210, 309-326.

Peakall, R., Smouse P. E., 2012: GenAlEx 6.5: genetic analysis in Excel. Population genetic software for teaching and researchan update. Bioinformatics 28, 2537-2539.

Peel, L. M. C., Finlayson, B. L., Mc Mahon, T. A., 2007: Updated world map of the Köppen-Geiger climate classification. Hydrology and Earth System Sciences 11, 1633-1644.

Petrželová, I., Lebeda, A., 2011: Distribution of race-specific resistance against Bremia lactucae in natural populations of Lactuca serriola. European Journal of Plant Pathology 129, 233-253.

Powell, W., Morgante, M., Andre, C., Hanafey, M., Vogel, J., Tingey, S., Rafalsky, A., 1996: The comparison of RFLP, RAPD, AFLP and SSRs (microsatellite) markers for germplasm analysis. Molecular Breeding 2, 225-238.

Pritchard, J. K., Stephens, M., Donnelly, P., 2000: Interference of population structure using multilocus genotype data. Genetics 155, 945-959.

Riar, D. S., Rustgi, S., Burke, I. C., Gill, K. S., Yenish, J. P., 2011: EST-SSR Development from 5 Lactuca species and their use in studying genetic diversity among L. serriola biotypes. Journal of Heredity 102, 17-28.

Rosenberg, N. A., 2004: Distruct: a program for the graphical display of population structure. Molecular Ecology Notes 4, 137-138.

Rydberg, H. 2013: Taggsalat - en art under spridning (Lactuca serriola on the increase in Sweden). Svensk Botanisk Tidskrift 107, 322-328 (in Swedish).

Simko, I., 2009: Development of EST-SSR markers for the study of population structure in lettuce (Lactuca sativa L). Journal of Heredity 100, 256-262.

Stebbins, G. L., 1957: Self-fertilization and population variability in the higher plants. The American Naturalist 91, 418-428.

Strausbaugh, P. D., Core, E. L., 1978: Flora of West Virginia, 2nd ed. Seneca Books, Grantsville, West Virginia.

Šilc, U., Košir, P., 2006: Synanthropic vegetation of the city of Kranj (Central Slovenia). Hacquetia 5, 213-231.

Tilman, D., 1988: Plant strategies and the dynamics and structure of plant communities. Princeton University Press, Princeton, NJ.

Uwimana, B., D'Andrea, L., Felber, F., Hooftman, D. A. P., den Nijs, H. C. M., Smulders, M. J. M., Visser, R. G., Van De Wiel, C. C., 2012: A Bayesian analysis of gene flow from crops to their wild relatives: cultivated (Lactuca sativa L.) and prickly lettuce (L. serriola $L$.) and the recent expansion of $L$. serriola in Europe. Molecular Ecology 21, 2640-2654.

van de Wiel, C. C. M., Sretenović Rajičić, T., van Treuren, R., Dehmer, K. J., van der Linden, C. C., van Hintum. Th. J. L., 2010: Distribution of genetic diversity in wild European populations of prickly lettuce (Lactuca serriola): implications for plant genetic resources management. Plant Genetic Resources $8,171-181$.

Vavilov, N. I., 1950: The Origin, Variation, Immunity and Breeding of Cultivated Crops. Waltham, Massachusetts, USA, Chronica Botanica, 13, 368.

Vos, P., Hogers, R., Bleeker, M., Reijans, M., van de Lee, T., Hornes, M., Frijters, A., Pot, J., Peleman, J., Kuiper, M., Zabeau, M., 1995: AFLP: A new concept for DNA fingerprinting. Nucleic Acids Research 23, 4407-4414.

Wang, C. M., Chen, C. H., 2010: Lactuca serriola (Asteraceae), a newly naturalized plant in Taiwan. Taiwania 55, 331-333.

Weaver, S. E., Downs, M. P., 2003: The biology of Canadian weeds. 122. Lactuca serriola L. Canadian Journal of Plant Science 83, 619-628.

Webb, C. J., Sykes, W. R., Garnock-Jones, P. J., 1988: Flora of New Zealand, volume IV. Botany Division, D.S.I.R., Christchurch.

Werk, K. S., Ehleringer, J., 1986: Effect of nonrandom leaf orientation on reproduction in Lactuca serriola L. Evolution 40, 1334-1337.

Zohary, D., 1991: The wild genetic resources of cultivated lettuce (Lactuca sativa L.). Euphytica 53, 31-35.

Zuloaga, F. O., Morrone, O., 1999: Catálogo de las Plantas Vasculares de la República Argentina. II. Acanthaceae-Euphorbiaceae (Dicotyledoneae). Monographs in Systematic Botany from the Missouri Botanical Garden 74 (in Spanish). 